\title{
Erratum to: A new technique for laparoscopic anterior resection for rectal endometriosis
}

\author{
James English • Jolyon Ford • W. F. Anthony Miles
}

Published online: 16 March 2011

(C) Springer-Verlag 2011

\section{Erratum to: Gynecol Surg}

\section{DOI 10.1007/s10397-005-0101-0}

The article is retracted due to a duplicated submission/ publication of the work published in Journal of the Society of Laparoendoscopic Surgeons. 